\title{
COMPARISON OF WASTE MANAGEMENT SYSTEMS IN WESTERN AND TRANSITION ECONOMIES WITHIN THE WATRA PROJECT
}

\author{
Roman Maletz ${ }^{1, *}$, Stephanie Wohmann ${ }^{1}$ and Alexandra Pukhnyuk ${ }^{2}$ \\ ${ }^{1}$ Institute of Waste Management and Circular Economy, Technische Universität Dresden, Pratzschwitzer Str. 15, D-01796 Pirna, Germany \\ 2 Institute of Waste Management, University of Natural Resources and Life Sciences, Vienna, Muthgasse 107/III, 1190 Vienna, Austria
}

Article Info:

Received:

8 February 2018

Revised:

18 May 2018

Accepted:

20 June 2018

Available online:

30 June 2018

Keywords:

Transition economy

Waste management development

Comparison

Reduction of landfilling

Recycling rates

\section{ABSTRACT}

The transition from a planned to a market economy has been a great challenge for all post-socialist states of the former Eastern Bloc. Public services which were to a major extent previously subsidized by the state needed to be adapted to new economic realities. This paper will present some of the results of a country overview report. This report represents the first working package of the WaTra project, which aims to help understand and develop the waste management systems of selected transition economies. 13 European and post-Soviet countries were chosen with different starting conditions and economic states to investigate which are the crucial factors in enabling the development of modern waste management. The countries considered were compared with each other using indicators of waste management. Waste collection, waste treatment, landfilling, recycling, composting and incinerated waste per capita are the main aspects taken into account and set in relation to economic indicators. Western EU countries generate higher amounts of waste per capita and have higher recycling rates. Landfilling is the major waste treatment method in post-Soviet and Eastern European countries, even among the EU states. The change from practices of only landfilling to modern waste management systems with high recycling and recovery is more recognizable. The more developed a country's waste management system is, the more waste is generated according to the strengthening of its economy.

\section{INTRODUCTION}

\subsection{WaTra Project}

Transition from a planned to market economy has been a great challenge for all post-socialist states of the former Eastern Bloc. Public services which were previously to a major extent subsidized by the state needed to be adapted to the new economic realities. In this respect, the municipal waste management sector (WM) is usually the most problematic due to its chronic state of underfinancing, noticeable influence on the urban image, as well as significant negative impact on the environment. The goal of the currently running WaTra project (Waste in Transition Economies) is to support the sustainable reformation process of the waste management sector in Belarus and the Ukraine through the enhancement of international cooperation and capacity building at partner universities and other stakeholders in the field of waste management (see projects homepage: http://watra.boku.ac.at/).

\subsection{Overview Report}

As a first step in the WaTra project, the waste manage- ment systems of 13 post-socialist and post-Soviet countries as well as non-socialist EU countries were described and analyzed. Countries for analysis were selected based on population size, varying waste management performance, preferred treatment technologies and governance system (decentralized/centralized, democratic/autocratic), availability of information (for post-Soviet states). The results of this data collection are merged within Task 1.2: "Comparison of WM Systems in Western and Transition Economies (Overview report)". It consists of 415 pages and gathers all information about the countries' profiles and related waste management information, including comments on data availability and scientific validation.

The main results are presented in this paper (Wohmann et al. 2016). In the report all used references from the respective country overviews could be find, above this data from the European statistical office and from d-waste atlas (www.atlas.d-waste.com) has been used. Therefore in the paper it is referenced to this report and the primary sources are not listed in the references (Table 1).

The countries considered were compared with each other using waste management indicators. Waste collec- 
TABLE 1: List of countries in which waste management systems have been described in the WaTra project.

\begin{tabular}{|c|c|c|c|}
\hline & Country & Political Development & Selection Reason for the Analysis \\
\hline 1 & Poland & Post-socialist (EU) & Well-developed medium-performing large post-socialist country \\
\hline 2 & GDR / Germany & $\begin{array}{l}\text { Post-socialist (EU) / Non-so- } \\
\text { cialist (EU) }\end{array}$ & $\begin{array}{l}\text { Best performing large post-socialist country (former GDR) } \\
\text { Best performing large non-socialist country with highest recycling rates (western } \\
\text { Germany - former FRG) }\end{array}$ \\
\hline 3 & Estonia & Post-Soviet (EU) & Best performing small post-Soviet country \\
\hline 4 & Austria & Non-socialist (EU) & Best-performing mid-sized non-socialist country with highest composting rates \\
\hline 5 & Denmark & Non-socialist (EU) & Best performing small non-socialist country with highest WTE rates \\
\hline 6 & Italy & Non-socialist (EU) & $\begin{array}{l}\text { Typical medium performing large non-socialist country with decentralized gover- } \\
\text { nance }\end{array}$ \\
\hline 7 & UK & Non-socialist (EU) & Medium performing large non-socialist country with centralized governance \\
\hline 8 & Belarus & Post-Soviet & $\begin{array}{l}\text { Project main country; mid-sized post-Soviet country with centralized/autocratic } \\
\text { governance }\end{array}$ \\
\hline 9 & Ukraine & Post-Soviet & $\begin{array}{l}\text { Project main country; large post-Soviet country with democratic governance (EU } \\
\text { accession candidate) }\end{array}$ \\
\hline 10 & Russia & Post-Soviet & $\begin{array}{l}\text { WM system determining country before transition; large post-Soviet country with } \\
\text { centralized/autocratic governance }\end{array}$ \\
\hline 11 & Kazakhstan & Post-Soviet & Mid-sized post-Soviet country with centralized/autocratic governance \\
\hline 12 & Moldova & Post-Soviet & $\begin{array}{l}\text { Typical small post-Soviet country with democratic governance (EU accession can- } \\
\text { didate) }\end{array}$ \\
\hline 13 & Georgia & Post-Soviet & $\begin{array}{l}\text { Typical small post-Soviet country with democratic governance (EU accession can- } \\
\text { didate) }\end{array}$ \\
\hline
\end{tabular}

tion, waste treatment, landfilling, recycling, composting and incinerated waste per capita are the main criteria that were taken into account and set in relation to economic indicators. In that case, the years 1995 and 2014 were considered. Over the period from the 1990s until to today, the post-socialist EU states and the Soviet states had the same requirements in the beginning. However, the waste management systems differed strongly. The few available data for the period before the 1990s are also taken into account.

It will be shown how and for what reasons the post-socialist EU states and "old" EU countries developed much better than the post-Soviet states after the collapse of the Socialist bloc from a waste management point of view. Performance of the old socialist centralized waste management system and the challenges of the transition period in the post-socialist / post-Soviet states are addressed. The development paths for waste management in the countries considered during the last 25 years were compared and main influencing factors (economic, governance, etc.) determined.

\subsection{Data collation}

The gathering of all comparison data was done by the scientists and students involved during the project. It quickly became obvious that there is a relationship between the developmental state of the country and the data availability. The same conclusions can be drawn by looking at the waste management stage of the country and its related data. In countries with low waste management performance, it was difficult to get official statistical data. This was caused by poor administrative infrastructure and awareness of this topic. In these cases estimates often had to be made by the few experts and scientists working in this field in the lacking countries. For the comparison countries in Western Europe, official statistical numbers could also be used with a higher temporal resolution stretching back to the political turning point in 1990. For the time before that, the data situation was poor for every country considered. Therefore, it had been tried to gather data from the years after 1990, and similar values in the years before the breakdown of socialism are assumed.

\section{COMPARISON}

The waste management situation and the development of the waste industry in post-socialist states, the "old" EU member states and the post-Soviet states over the past 30 years were explained in detail in the related report as outcomes of the WaTra project. Waste sectors have developed differently in the countries considered - not only regarding treatment processes and operations, but also the temporary state of development. Waste management development of a country undergoes different development phases. Klampl et al. (2006) classifies 5 stages, see Table 2.

The countries considered represent the whole range of these developmental stages. The western European countries can be seen to have almost reached phase 5 with some potential for higher quotas of secondary raw material streams. Most new European member states or post-Soviet states are situated in phases 1 to 2 , and even phase 0 can be found in rural areas.

In the report generated, waste, treated waste (which in this report means collected waste), landfilled waste, recycling, composting, incineration, the GDP and the unemployment rates of those countries will be compared.

For post-Soviet countries that have no strict information policy, data availability is poor. In order to become an EU member, comprehensive waste data management 
TABLE 2: Phases of waste management development - adapted from Kampl et al. (2006).

\begin{tabular}{c:l}
\hline Phase 0 & Neglect \\
\hdashline Phase 1 & Collection and uncontrolled disposal \\
\hdashline Phase 2 & Controlled disposal \\
\hdashline Phase 3 & Collection logistics \\
\hdashline Phase 4 & Recovery solutions \\
\hdashline Phase 5 & Industrial cycle of (secondary raw) materials \\
\hline
\end{tabular}

is required. Information from EU member states is easily available, although the degree of aggregation has to be validated. Yet the information from post-Soviet states is fragmentary.

The countries Poland, Germany and Estonia will be regarded as post-socialist EU member states. Austria, Denmark and Italy are considered "old" EU member states. Post-Soviet states include the following countries: Belarus, Kazakhstan, Russia, Ukraine, Georgia and Moldova.

Municipal waste is considered to be waste collected through waste removal systems in private households or public institutions. It is used synonymously with the term "collection of waste." In the event that there is no waste removal system, the amounts are estimated by the participating research group. The "total waste treatment" depicts the treatment of the overall collected waste, and therefore unrecorded waste is excluded. The informal sector is estimated to differ strongly. Treatment methods of waste for this study are incineration, composting, recycling and dumping/landfilling.

Table 3 shows the percentages of incineration, composting, recycling and landfilling of the collected waste. The data are given in $\mathrm{kg}$ per capita per year.

As seen in Table 4, there was an evaluation established by BiPRO (2012) to assess the waste management developmental stage of a country. For the report, the 6 countries Belarus, Russia, Ukraine, Kazakhstan, Moldova and Georgia were calculated by the project team. It was found that as expected, the 6 countries are on a low waste managemental level compared to the EU member states for which the assessment was conducted in BiPRO (2012).

\subsection{Generated Waste}

The following figure shows the produced waste per capita in 1995 and 2014. In 1995, more waste was accumulated in post-socialist countries than in 2014. Until 2014 a small decrease can be seen. For example, in Germany, $623 \mathrm{~kg}$ of waste per capita was generated in 1995, and in 2014 it was $618 \mathrm{~kg}$ per capita (Figure 1).

The "old" EU member states produced less waste in 1995 than in 2014. The amounts increased especially for Denmark. Whereas there was only $521 \mathrm{~kg}$ of waste per capita in 1995, Danish population produced $758 \mathrm{~kg}$ of waste in 2014. The causes for Germany are known through the efforts of the environmental policy to decouple economic growth from the waste generated over the last 20 years.

Also, the post-Soviet states produced less waste in 1995 than in 2014. The biggest change was found for Belarus - the population produced $144 \mathrm{~kg}$ of waste per capita in 1995, and in 2014 it was $421 \mathrm{~kg}$ of waste per capita. This can be interpreted with the obvious positive correlation between economic development and waste amounts, unless countries are aiming to decouple explicitly in the policies, as is the case in Germany.

The increase for the transition countries can be explained by the industrial development and improved living conditions of the respective populations. Due to growing production, the ensuing supply of goods and improved liquidity, the consumption behavior of people has changed.

One has to bear in mind that the figure depicts merely the amount of collected waste. Any illegally collected or dumped waste cannot be taken into consideration and constitute unreported amounts.

\subsection{Landfilling}

When providing generation amounts of waste at the household level, data are often used from only a few small

TABLE 3: Waste amounts and rates for different treatment methods for 1995 and 2014 (UK, Belarus and Kazakhstan are not considered in this table).

\begin{tabular}{|c|c|c|c|c|c|c|c|c|c|c|}
\hline & \multicolumn{2}{|c|}{$\begin{array}{l}\text { Waste generated } \\
\text { [per capita in kg] }\end{array}$} & \multicolumn{2}{|c|}{$\begin{array}{c}\text { Landfill } \\
\text { [\% of generated waste] }\end{array}$} & \multicolumn{2}{|c|}{$\begin{array}{c}\text { Recycling } \\
\text { [\% of generated waste] }\end{array}$} & \multicolumn{2}{|c|}{$\begin{array}{c}\text { Composting } \\
\text { [\% of generated waste] }\end{array}$} & \multicolumn{2}{|c|}{$\begin{array}{c}\text { Incineration } \\
\text { [\% of generated waste] }\end{array}$} \\
\hline & 1995 & 2014 & 1995 & 2014 & 1995 & 2014 & 1995 & 2014 & 1995 & 2014 \\
\hline Poland & 280 & 272 & 99 & 52 & 0 & 21 & 1,8 & 11 & 0 & 15 \\
\hline Germany & 623 & 618 & 42 & 1,5 & 26 & 46 & 13 & 17 & 17 & 34 \\
\hline Estonia & 371 & 357 & 99 & 6 & 0 & 26 & 0,5 & 4,8 & 0 & 47 \\
\hline Italy & 454 & 488 & 92 & 32 & 3,5 & 25 & 1,3 & 16 & 5 & 19 \\
\hline Austria & 437 & 566 & 46 & 4 & 46 & 26 & 27 & 31 & 12 & 36 \\
\hline Denmark & 521 & 758 & 18 & 1,3 & 14 & 26 & 10 & 17 & 56 & 54 \\
\hline Russia & 101 & 330 & 90 & 90 & 10 & 10 & n.d. & n.d & n.d. & n.d \\
\hline Georgia & n.d. & 318 & 100 & 100 & 0 & 0 & 0 & 0 & 0 & 0 \\
\hline Moldova & n.d. & 650 & 100 & 100 & 0 & 0 & 0 & 0 & 0 & 0 \\
\hline Ukraine & 195 & 268 & 99 & 99 & 0 & 0 & 0 & 0 & 0 & 0 \\
\hline
\end{tabular}




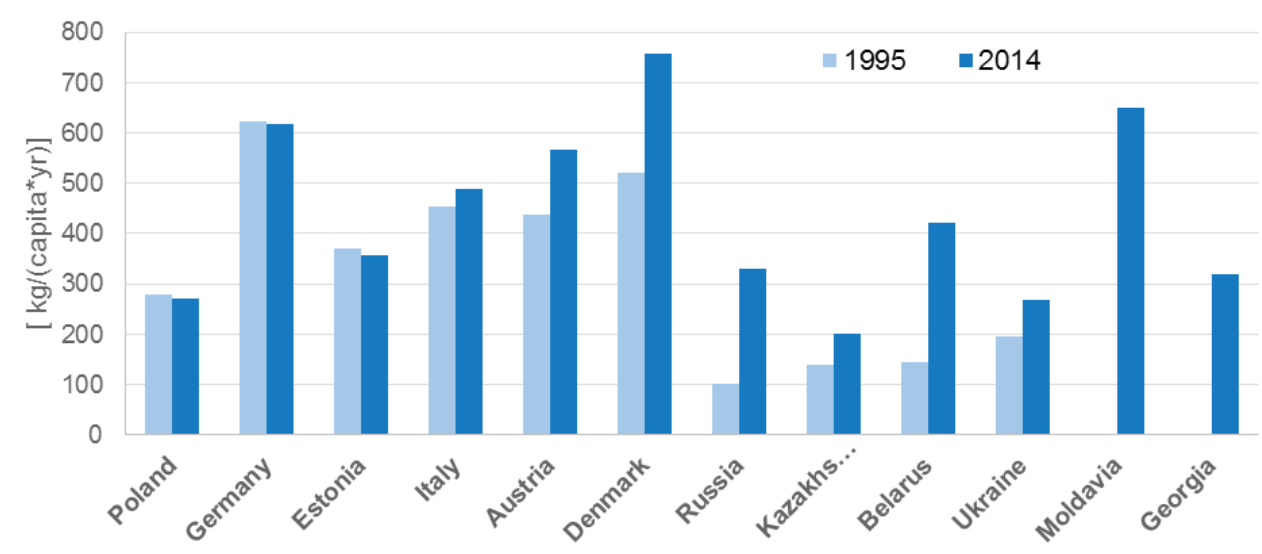

FIGURE 1: Waste generated per capita in 1995 and 2014 (for Ukraine, Moldova, Georgia, numbers for 2007 were used, no data were available for the period before 2000, and Russian data from 2004 and 2006), Wohmann et al. (2016).

surveys done voluntarily by related experts or by NGOs, especially in the countries considered with low waste management development. Sometimes generation rates are estimated by the amounts delivered to waste management facilities. In countries with a high share of landfilling, these data are similar to the waste generation. Therefore, it is useful to look at landfill amounts per capita. These numbers show only the amounts which are brought to official landfill sites, and in the better cases, these are already sanitary landfills with base sealing and suitable covering and collection systems for leachate and landfill gas.

Reducing landfilled waste amounts is always to be seen as one of the most important actions to improve a country's waste management situation. Landfilling leads to land consumption, landfill gas emissions and the deple- tion of resources that could instead be looped back into the economy through recycling and recovery (Maletz 2018).

Figure 2 shows the landfilling rate of waste for 1995 and 2014. This represents the amount of waste that was officially recorded or estimated by local experts at the public landfill sites as the rate of overall waste generation. Due to a lack of comprehensive statistical registering in some countries, partial estimates were used. It needs to be mentioned that post-socialist EU member states Estonia and Poland dumped 99 percent of their waste in 1995 while Germany dumped 42 percent of their waste in the same year. Until 2014, Poland reduced this amount to 50 percent. The reductions were higher in Estonia and Germany - Estonia dumped only 6 percent while Germany dumped 1.5 percent of the overall produced waste starting from a lower

TABLE 4: BiPRO Assessment for countries considered - BiPRO (2012) - and own calculations within the WaTra project, sorted from the highest to lowest result.

\begin{tabular}{|c|c|c|c|c|c|c|c|c|c|c|c|c|c|c|c|c|c|c|c|}
\hline & 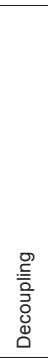 & 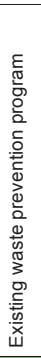 & 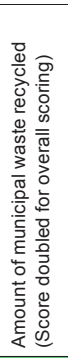 & 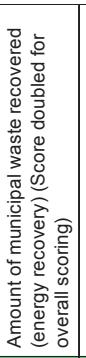 & 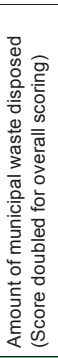 & 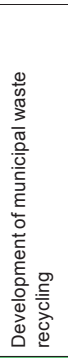 & 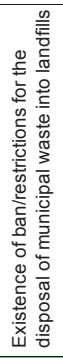 & 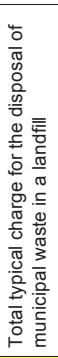 & 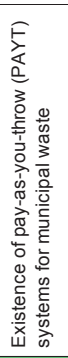 & 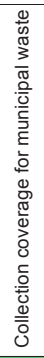 & 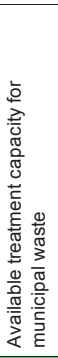 & 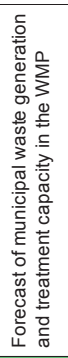 & 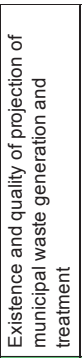 & 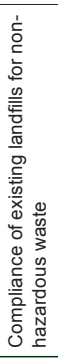 & 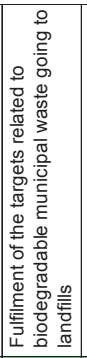 & 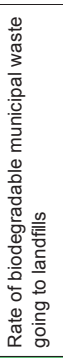 & 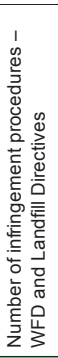 & 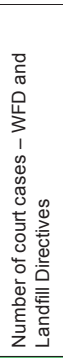 & 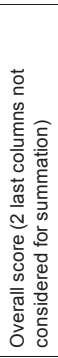 \\
\hline Austria & 0 & 2 & 2 & 2 & 2 & 2 & 2 & 1 & 2 & 2 & 2 & 2 & 2 & 2 & 2 & 2 & 2 & 2 & 35 \\
\hline Denmark & 0 & 0 & 2 & 2 & 2 & 2 & 2 & 2 & 1 & 2 & 2 & 2 & 2 & 2 & 2 & 2 & 2 & 2 & 33 \\
\hline GDR / Germany & 1 & 0 & 2 & 1 & 2 & 2 & 2 & 2 & 2 & 2 & 2 & 2 & 1 & 2 & 2 & 2 & 2 & 2 & 32 \\
\hline United Kingdom & 1 & 2 & 2 & 1 & 2 & 2 & 0 & 1 & 1 & 2 & 2 & 2 & 1 & 1 & 2 & 1 & 2 & 2 & 28 \\
\hline Poland & 1 & 2 & 1 & 0 & 1 & 2 & 1 & 1 & 1 & 0 & 2 & 0 & 0 & 1 & 0 & 0 & 1 & 2 & 15 \\
\hline Estonia & 2 & 0 & 1 & 0 & $\overline{0}$ & 0 & 1 & 1 & 1 & 0 & 2 & 0 & 1 & 2 & 2 & 1 & 1 & 1 & 15 \\
\hline Italy & 0 & 0 & 1 & 1 & 1 & 0 & 1 & 2 & 1 & 2 & 0 & 0 & 0 & 0 & 2 & 1 & 0 & 0 & 15 \\
\hline Belarus $^{*}$ & 1 & 2 & 1 & 1 & 0 & 2 & 1 & 0 & 0 & 0 & 1 & 0 & 1 & 1 & 0 & 0 & n.c. & n.c. & 13 \\
\hline Russia* $^{*}$ & 0 & 2 & 0 & 1 & 0 & 1 & 1 & 0 & 0 & 0 & $\overline{0}$ & 1 & 1 & $\overline{0}$ & 0 & 0 & n.c. & n.c. & 8 \\
\hline Ukraine $^{*}$ & 0 & 2 & 0 & 1 & 0 & 1 & 0 & 0 & 0 & 0 & 0 & 0 & 0 & 0 & 0 & 0 & n.c. & n.c. & 5 \\
\hline Kazakhstan* & 1 & 0 & 0 & 0 & 0 & 1 & 1 & 0 & 0 & 0 & 0 & 1 & 1 & 0 & 0 & 0 & n.c. & n.c. & 5 \\
\hline Moldova* $^{*}$ & 0 & 2 & 0 & 0 & 0 & 0 & 0 & 0 & 0 & 0 & 0 & 1 & 1 & 0 & 0 & 0 & n.c. & n.c. & 4 \\
\hline Georgia* $^{*}$ & n.c. & 2 & 0 & 0 & 0 & 0 & 0 & 0 & 0 & 0 & 0 & 0 & 0 & 0 & 0 & 0 & n.c. & n.c. & 2 \\
\hline
\end{tabular}

* calculated in WaTra project

n.c. - not calculated 


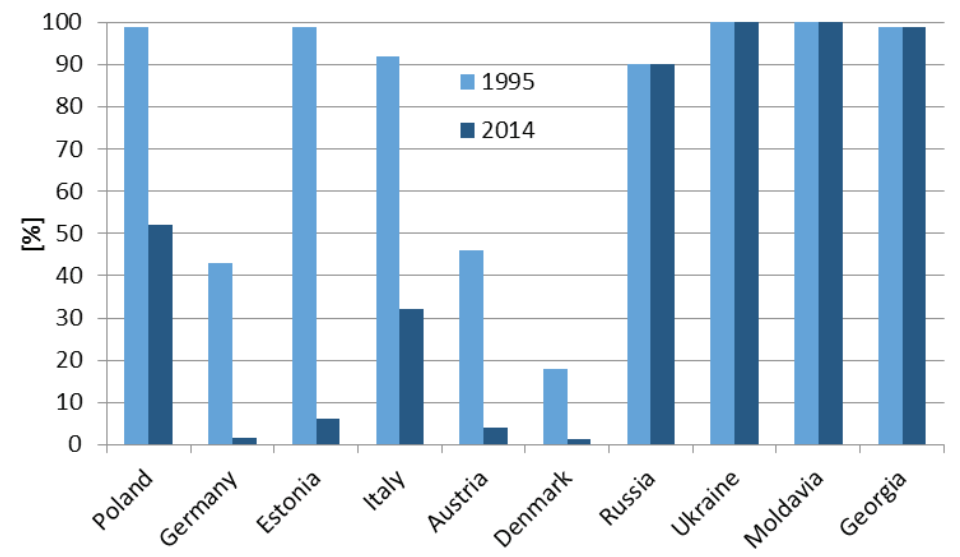

FIGURE 2: Landfilling rate in 1995 and 2014, Wohmann et al. (2016)

dumping level already. The example of Estonia can be seen as a best practice through massive efforts from the Estonian administration. A supporting effect is the small size of the country and the membership in the EU, where funding for an improving waste management situation can be requested, which was extensively used in several projects (Fischer 2013). Furthermore, this is caused by a strong enforcement of environmental law. Economic development also helps make investments in environmental technology possible.

There are still big differences between the "old" EU member states in a similar developmental stage. In 1995 Italy landfilled 92 percent of its waste, Austria disposed 46 percent and Denmark 18 percent of its waste in landfills. Until 2014 there were the following reductions: Italy reduced to 32 percent, Austria decreased to 4 percent and Denmark reduced the amounts to 1.3 percent.

For the post-Soviet states, data was available only for Georgia, Moldova, Russia and the Ukraine. These countries dump a similar amount of waste. Russia dumps circa 90 percent of its waste (VDMA 2015). If the waste accumulation is $330 \mathrm{~kg}$ per capita, this amounts to 297 $\mathrm{kg}$ of dumped waste per capita. Georgia and Moldova do not treat their waste in measurable amounts, and thus all waste is dumped. The Ukrainian numbers tell us that currently around $230 \mathrm{~kg}$ of waste is landfilled per capita and per year. The absolute amount of landfilled waste per capita can be adduced for estimating the environmental impacts through landfilling, such as the emission of climate gases like landfill gas and $\mathrm{CO}_{2}$.

\subsection{Recycling}

Figure 3 indicates the amount of recycling per capita in 1995 and 2014. After collection, most of the waste produced goes through the procedure of materials recycling. For the post-Soviet countries, data could not be provided for all countries. Statements can only be made about the Ukraine, Russia, Moldova and Georgia.

During the 1990s, there was no materials recycling in Poland or Estonia. Compared to that, in 1995, Germany recycled 26 percent and in 2014, 46 percent of its overall waste produced. Around 50 percent of all waste is recycled in Germany and flows as secondary raw materials into the production cycle.

From the "old" EU member states Austria is most interesting, as the recycling rate decreased from 46 percent in 1995 down to 25 percent in 2014 . This can be explained by the fact that Austria uses more of its municipal solid waste for waste-to-energy processes. The more common development towards higher rates can show Denmark and Italy, whereas Italy's recycling increased from 3.5 percent in 1995 to 26 percent in 2014, and Denmark increased from

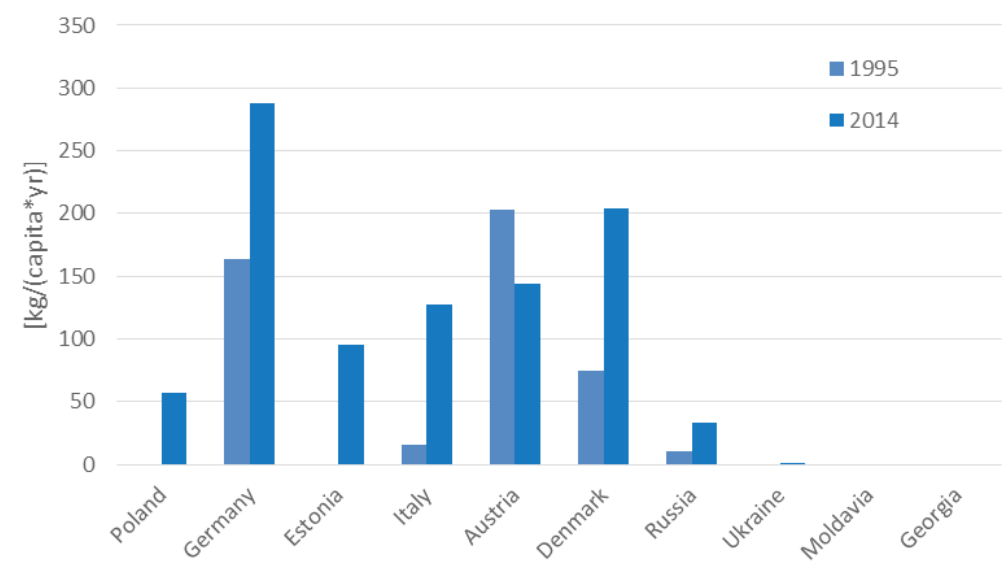

FIGURE 3: Materials recycling per capita in 1995 and 2014 (Belarus and Kazakhstan not considered), Wohmann et al. (2016). 
14 percent to 26 percent.

Russia recycled only approximately 10 percent of its overall waste generated (VDMA 2015). Georgia and Moldova did not manage any kind of recycling in past years, though there is some small development apparent in its current situation. No statements can be made about Kazakhstan and Belarus, as there is a lack of data for both countries. The Ukraine recycled a very small part of it its collected waste, and the recycling rate given was approximately $0.09 \mathrm{~kg}$ per capita and per year.

\subsection{Composting}

Figure 4 indicates the amount of composted waste per capita in 1995 and 2014. A comparison ensues here merely between the "old" EU member states and the post-socialist EU states. In post-Soviet countries like Georgia, the Ukraine and Moldova, there were officially no composting amounts registered. For Kazakhstan, Russia and Belarus there were no numbers available.

The figure shows that the "old" EU member states compost much more than the post-socialist states.

As for the post-socialist EU member states, Germany composted most of its waste both in 1995 and 2014. In 1995, 13 percent, and in 201417 percent of the overall waste was composted in Germany. Poland and Estonia showed a significant increase - especially Poland went from 1.8 percent in 1995 to 11 percent in 2014. Estonia composted only 0.5 percent (1995) and 2.8 percent (2014) of its overall waste. In 1995, neither the state-of-the-art nor the capacities were sufficient to build composting plants or provide the required capacities. A higher share of waste was treated with other methods. The population's own efforts to compost in their own gardens were not included in the analysis, although they could raise the proportional amount of composting significantly, as green waste and garden waste amount to a considerable amount of waste. Especially for Belarus and the Ukraine as joint project partner countries, a very high share of home composting could be identified, and increasingly investigated in the rural areas.

Compared to the other "old" EU member states, Austria has the highest share of composting of its overall waste produced. The share increased from 27 percent in 1995 to 31 percent in 2014. In Denmark, composting rose during the same period from 10 percent to 17 percent, and in Italy from 1.3 percent to 16 percent.

\subsection{Incineration}

Figure 5 presents the incinerated waste amounts per capita in 1995 and 2014. There was no data generated in the post-Soviet countries Russia, Kazakhstan and Belarus. Statements can only be made about the Ukraine, Moldova and Georgia. For the post-Soviet EU member states, there

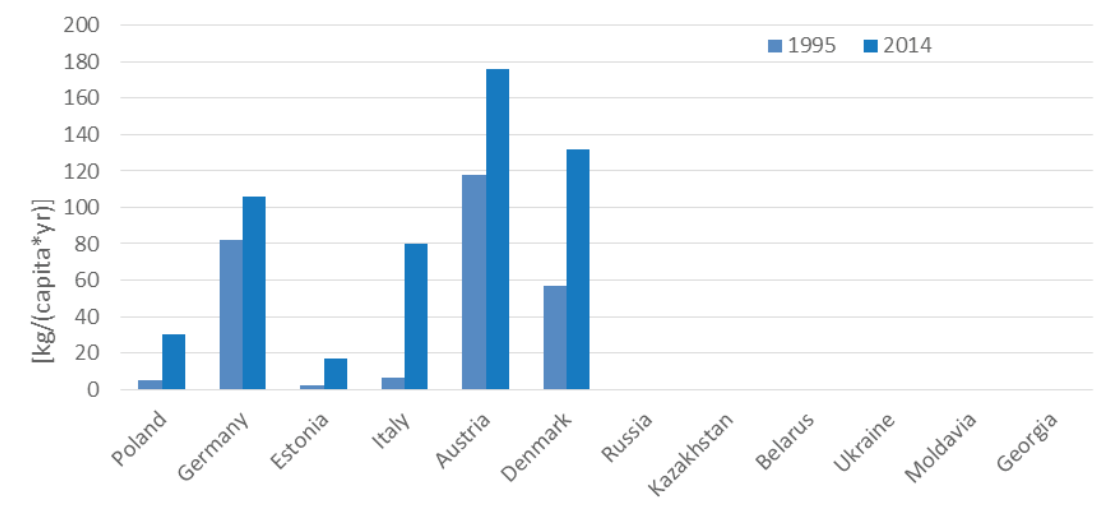

FIGURE 4: Composting per capita in 1995 and 2014, Wohmann et al. (2016)

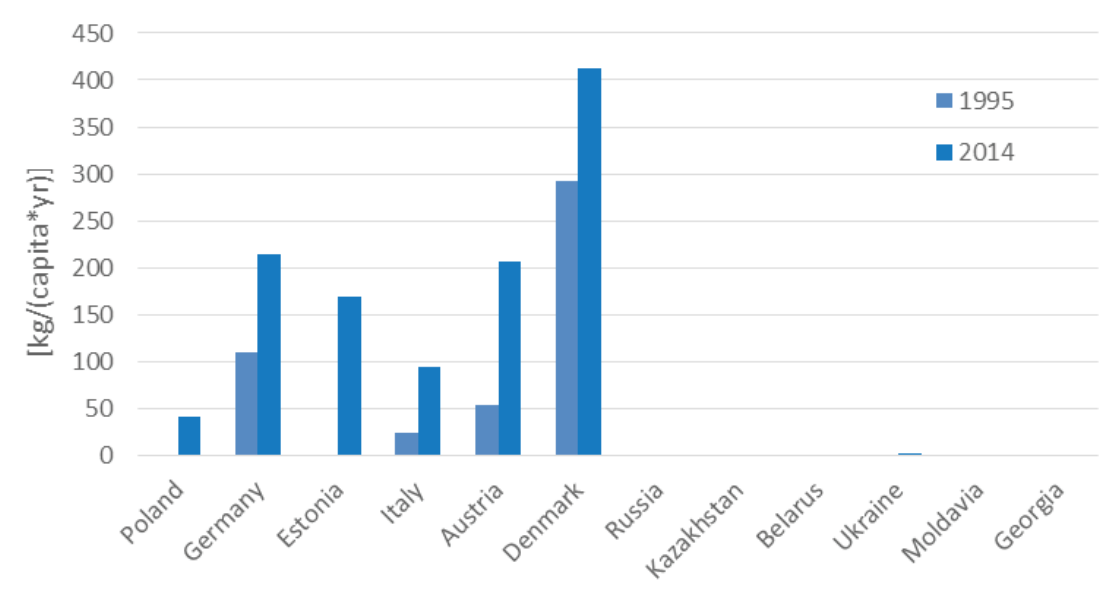

FIGURE 5: Total incineration per capita in 1995 and 2014 (no data for Belarus and Kazakhstan; in Georgia, Moldovia, Russia and the Ukraine, the amounts of incinerated waste were considered negligible), Wohmann et al. (2016). 
was merely a comparable figure for Germany in 1995, as no incineration plants existed in Poland or Estonia. In 1995, Germany treated only 17 percent and in 2014, 34 percent of the overall collected waste in incineration plants. Energy for heating and electricity was generated through this thermal process. In 2014, Estonia captured 47 percent of its waste per capita as an energy resource through incineration. Due to the possible energy gain, incineration has a high importance in Estonia. In 2014, Poland treated 15 percent of the overall waste produced per capita in incineration plants. There are only a few Polish incineration plants, and thus the waste has to be treated in other ways.

Among the "old" EU states, Denmark has the highest amount of incineration. Small and economically strong countries like Denmark, besides Switzerland and the Netherlands, concentrate on waste to energy for their residual waste stream due to less geographical space and high energy and heat demand. In 1995, Denmark treated 56 percent and in 201454 percent of the overall waste produced per capita in incineration plants, which is $100 \%$ of the residual waste. Both in Italy and Austria, the amount of incinerated waste has risen significantly from 1995 until 2014. In 1995, Italy treated 5 percent and in 2014, 19 percent of its total waste by incineration. For Austria it was found that in 1995, 12 percent, and in 2014, 36 percent of the overall waste produced was incinerated. As for the post-Soviet states, only the Ukraine treated its waste, with very small share in incineration plants with a low technological standard. The figures here amount to $0.06 \mathrm{~kg}$ per capita. In Moldova and Georgia, there was no incineration of waste until now. The small incinerators which can be found partly in hospitals in these countries are not being considered in this comparison.

\subsection{GDP and the unemployment rate}

Developing a country's waste sector, social aspects and economic differences have to be taken into account. Among others, the development of a waste management system affects the gross domestic product (GDP) and the unemployment rate as the basic economic parameters. The following figures depict the differences concerning GDP and unemployment in post-socialist EU states, the "old" EU member states and the post-Soviet states. The social and financial differences merge in the willingness of citizens to introduce new waste systems, especially waste collection schemes.

The GDP summarizes the value of all goods and services of a particular amount of time generated in a person's country. It is of importance to check whether the economic effort is achieved by a national or foreign citizen.

Apart from that, the GDP is often compared to the prosperity of a country. Yet it remains problematic that GDP as an instrument to measure prosperity does not indicate whether the government's funds are invested wisely. Environmental exploitation and the waste of natural resources may have a positive effect on the economy and raise the GDP. Statistically, this would be an increase in the GDP. Apart from that, illegal employment, barter, shadow economy and subsistence economy cannot be ignored, as they form the livelihood for many poorer citizens. Yet these "industries" are not taken into the GDP's figures.

Furthermore, the GDP serves as an indicator for economic growth. It is indicated by the rise of the GDP. An increase in economic power is based on an increase in productivity, which is influenced by:

\section{- physical capacity (machines) \\ - human capacity (employees) \\ - natural resources \\ technical knowledge}

Figure 6 depicts the GDP per capita in euros. It shows the increase of the GDP per capita from 1995 to 2014. In addition, the GDP in the "old" EU member states and the post-socialist countries was significantly higher than in the post-Soviet states.

In the post-socialist EU states, the 1995 GDP was clearly below the GDP average in 2014. Germany's GDP amounted to 23,000 euros per capita in 1995 , and 37,100 euros per capita in 2014.

The GDP of the "old" EU member states is clearly above the overall average of the other countries compared. In 1995 , Denmark's GDP amounted to 26,600 euros per capita, and in 2014 it was 46,800 euros per capita.

The GDP of the post-Soviet states is distinctly below

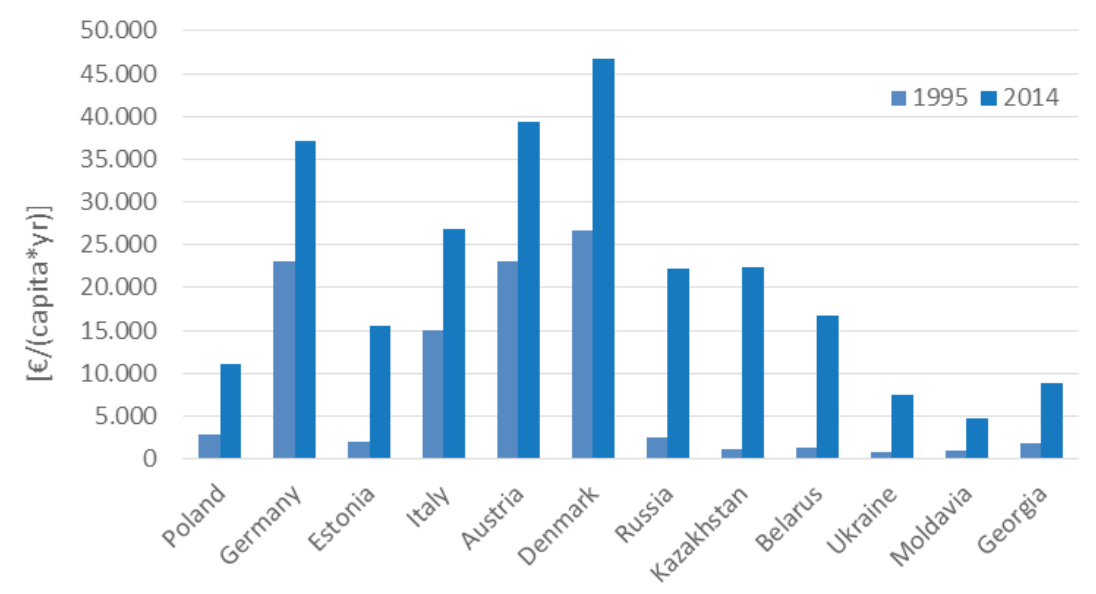

FIGURE 6: GDP per capita in 1995 and 2015, Wohmann et al. (2016). 
the average of the EU member states. The Ukraine had the lowest GDP in 1995 - only 875 euros per capita. In 2014 the Ukrainian GDP rose to 7,500 euros per capita. The lowest GDP was in Moldova - 4,700 euros per capita.

From the figure above, it emerges that countries with a longer EU membership have a clearly higher GDP. Examples are Denmark, Austria, Italy and Germany. Poland and Estonia joined the EU later.

Unemployment is the lack of employment opportunities for parts of the population that are both able to work and seeking work. In many countries around the world, unemployment is one of the biggest macroeconomic challenges, as it causes high social costs.

Figure 7 illustrates the unemployment rate in 1995 and 2014. The unemployment rate was higher in 1995 than in 2014 in post-socialist countries. 8.2 percent of the German population able to work was unemployed in 1995. Until 2014 , the unemployment rate sank to 5 percent.

In the "old" EU member states, a similar tendency prevails. Italy has the highest unemployment rate: it was 11.2 percent in 1995 and 12.7 percent in 2014. The Danish unemployment rate is, however, identical for 1995 and 2014 -6.6 percent.

For the post-Soviet countries, the unemployment rates of 2006 and 2014 were compared, as no earlier data is known. There was a higher unemployment rate in 2006 than in 2014. Georgia had the highest unemployment rate: in 2006 it was 13.6 percent and in 2014 it was 13.4 percent. The biggest decrease in unemployment happened in Moldova - from 7.4 percent in 2006 to 3.9 percent in 2014, with its strong industry sector as one possible explanation.

The figures for unemployment are closely related to the financial concerns of the population. The more unemployed people, the more people struggle with financial problems and existential fears. This is a factor that influences the population's willingness to implement and accept a new industrial waste system.

The relationship between unemployment and GDP or economic growth is explained through Okun's Law. Arthur Okun first described the correlation between the two aspects based on his empirical observations. His law states that an increase in the unemployment rate by 1 percent costs 2.5 percent of economic growth. However, a reverse scenario can also be observed: It takes 2.5 percent of eco- nomic growth in order to decrease unemployment by 1 percent. One has to bear in mind that the exact percentage varies depending on the type of national economy and has to be adjusted anew.

To achieve a decrease in unemployment by boosting economic growth, it needs a so-called "employment surge." This surge characterizes a growth rate that is required as a minimum in order to secure current employment. Among other factors, the extent of the employment surge is defined by technological progress - because the higher the productivity, the less human capital is necessary to achieve the same GDP.

Figure 8 depicts the dependency of the GDP per capita and the unemployment rate in 1995 and 2014.

The figure illustrates the employment surge between 1995 and 2014. In 1995, Estonia, Germany, Austria and Denmark had low unemployment rates and sufficiently high economic growth. This means the employment surge was successful. The economic growth was sufficient to curb or decrease unemployment. In 2014 this applied to Germany, Austria, Denmark, Russia, Kazakhstan and Belarus. In 1995 the following countries had no successful employment surge: Georgia, Moldova, Ukraine, Belarus, Kazakhstan, Russia and Italy. As a consequence, unemployment rates went up. In 2014 this could be observed in Poland, Estonia, Italy, Ukraine, Moldova and Georgia.

Germany, Austria and Denmark achieved an employment surge in 1995 and 2014. On the one hand, these countries exhibit a consistent social and financial standard and on the other hand, a consistently positive development in the waste industry. It can be speculated whether and how these factors are related to one another. However, based on that assumption, broader support from the population for waste industry issues is visible. Apart from that, the economic and political interests pursue a constant improvement of the waste industry and the related improvements for the environment. Neither Georgia, nor Moldova, the Ukraine or Italy had a successful employment surge in 1995 and 2014. This is another hint that poor social and financial standards are related to a lack of willingness and opportunities for citizens, politics and the economy to contribute to change and improvement of the waste industry and the environment.

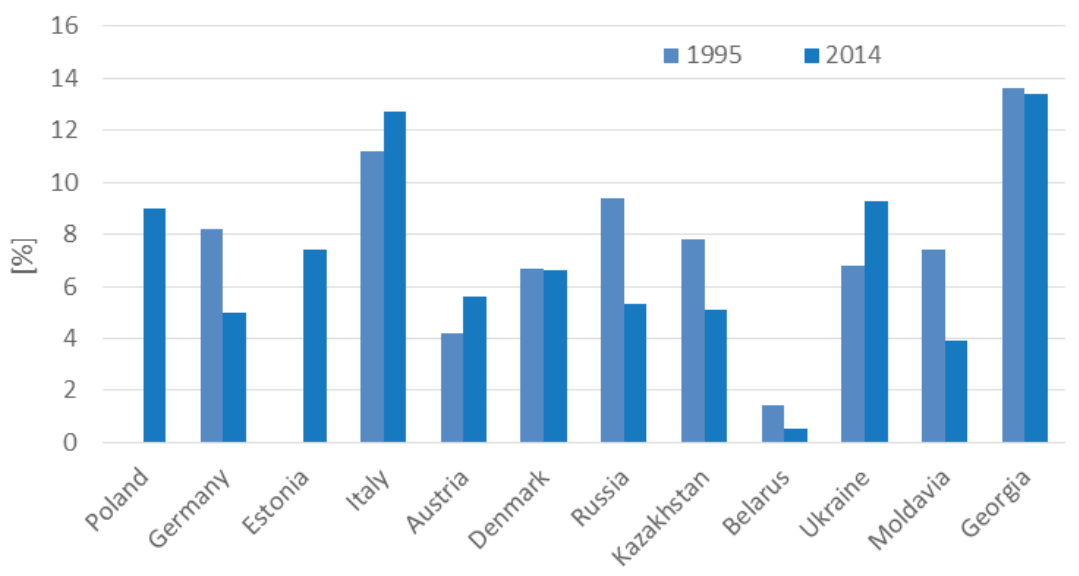

FIGURE 7: Unemployment rate in percent in 1995 and 2014, Wohmann et al. (2016) 


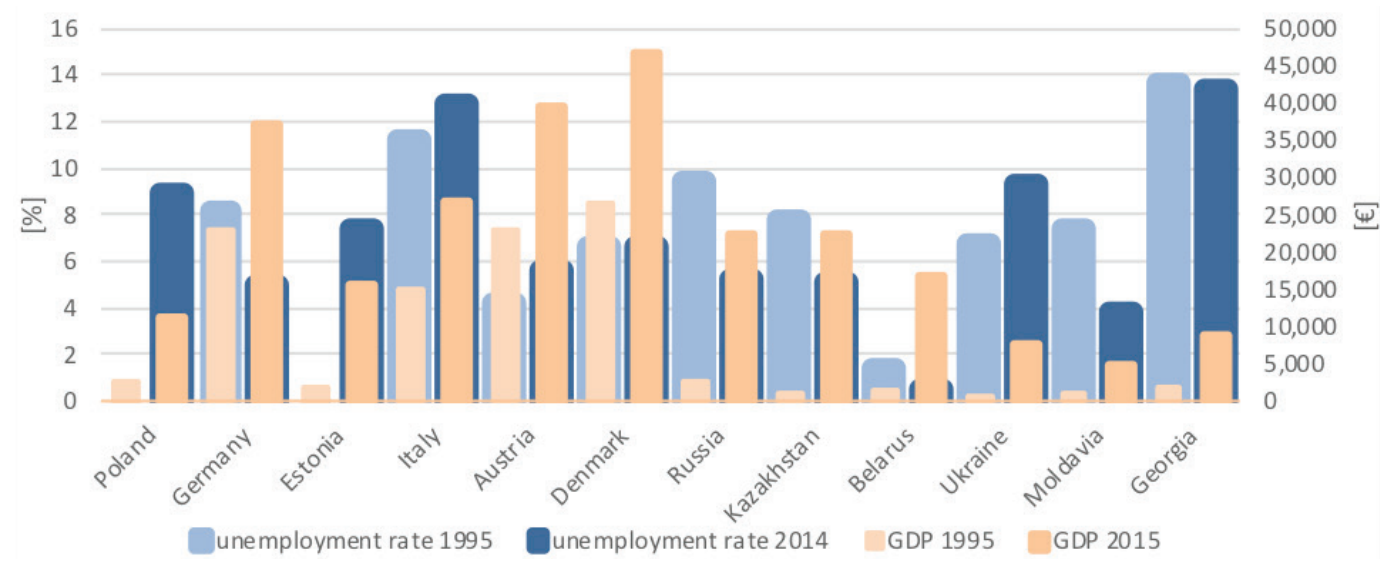

FIGURE 8: Relation of GDP per capita and unemployment rate.

\section{CONCLUSIONS}

Looking at the past socialist waste management system, there was a very efficient recycling system in the socialist economy. Shortage leads to efficient usage of material streams. Lots of uncontrolled dumping sites existed in the socalist countries. Recycling was not done for ecological reasons, but for economic. The partly ecoefficient waste management systems in socialist countries broke down after the collapse of the "Iron Curtain." For the future, it is necessary to implement a comprehensive data system. This is an important factor for measuring the performance and deriving improvements. Integration of the informal sector activities in the organized WM system can be a strong support for reducing the amounts of valuable waste streams going to landfills, especially where there is a lack of investment power in the waste management sector. Improving the waste sector has proven to be an ecological and economic opportunity for a developing country. Waste systems in the EU could be transferred to post-Soviet states (best practice examples for post-Soviet EU states. Countries with an EU orientation (GDR, former socialist EU states) had more opportunities to modernize their WM systems based on the model of existing western market oriented WM systems.

The project aimed to compare socialistic countries in Europe and the former Soviet Republic with some other European countries, because they have similar legislational conditions (EU-legislation) for their waste management development. Even the post soviet non EU states follow these regulations proved to be useful both for environmental protection and economic growth.

Further research could include other socialist countries not only European and former Soviet states. Waste compositions was not compared due to weak data availability, but should included in the further work in this field.

\section{AKNOWLEDGEMENTS}

The authors would like to express their grateful thanks to the WaTra project team and the students involved in the WaTra project that contributed to the study.

\section{REFERENCES}

BiPRO (2012). Screening of Waste Management Performance of EU Member States. Report ordered by the European Commission, Directorate-General, Environment.

Edler D. and Blazejczak J. (2015). Beschäftigungswirkungen des Umweltschutzes in Deutschland im Jahr 2012. Publication from the DIW ordered by the UBA, Germany (Ed.).

Fischer (2013). Municipal waste management in Estonia. Report prepared for the European Environment Agency.

Klampfl H., Gelbmann U., Schmidt G. (2006). Die Entwicklung der Abfallwirtschaft als Phasenmodell. In Quantensprünge in der Abfallwirtschaft - Entwicklung eines innovationsorientierten Phasenmodells der europäischen Abfallwirtschaft, Klampfl-Pernold, Gelbmann (Eds), Shaker, Aachen.

Maletz R. (2018). Success Factors for the Implementation of Separate Collection Systems. In: Maletz, Roman; Dornack, Christina; Ziyang Lou (Ed.): Source Separation and Recycling - Implementation and Benefits for a Circular Economy; The Handbook of Environmental Chemistry, Vol. 63; Springer Nature, Heidelberg. (https://doi.org/10.1007/698_2017_51)

VDMA (2015). Abfallwirtschaft Russland Siedlungsabfälle. Publication from German Mechanical Engineering Industry Association (VDMA). Accessed 1.12.2016.

Wohmann S., Maletz R., Abashyna K., Arlouski P., Chernikova O., Karpenko Y., Khandogina O., Melnikova I., Pavlova M., Scharenberg L., Shashanka S., Shilova I., Skryhan H., Stolberg F. (2016). Comparison of WM Systems in Western and Transition Economies (Overview report). Within the framework of the WaTra project. 